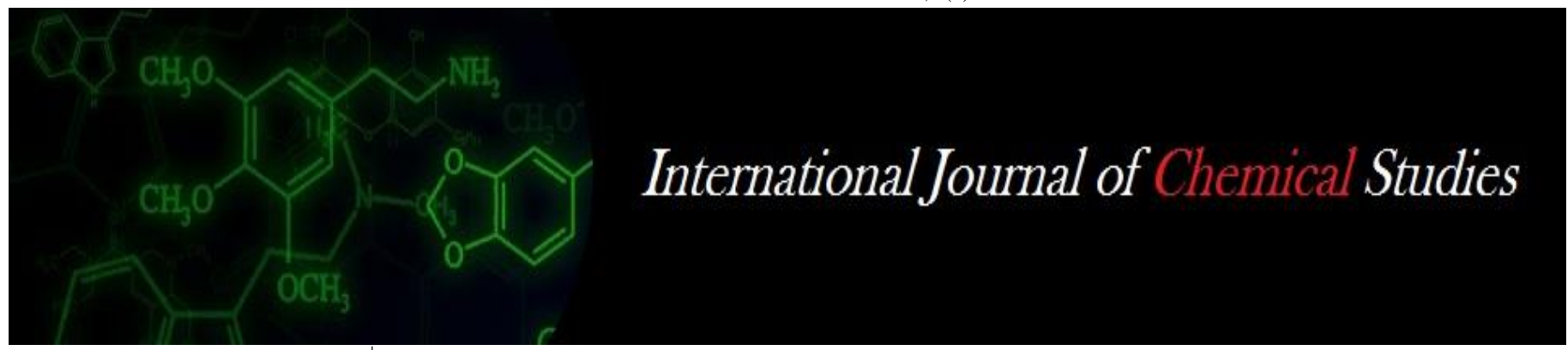

P-ISSN: 2349-8528

E-ISSN: 2321-4902

www.chemijournal.com

IJCS 2020; 8(5): 401-403

(C) 2020 IJCS

Received: 07-06-2020

Accepted: 15-08-2020

\section{Vipin Kumar}

Deptt. of Agricultural Chemistry \& Soil Science, R B S College Bichpuri Agra, Uttar Pradesh, India

\section{Nidhi Nagar}

Deptt. of Agricultural Chemistry \& Soil Science, R B S College Bichpuri Agra, Uttar Pradesh, India

Har Mohan Singh Yadav Deptt. of Agricultural Chemistry \& Soil Science, R B S College Bichpuri Agra, Uttar Pradesh, India

\section{Devendra Pal}

Krishi Vigyan Kendra Sambhal (SVPUA \& T Meerut)

Uttar Pradesh, India

BS Kherawat

SMS Soil Science, KVK,

Bikaner-II, Swami Keshwanand Rajasthan Agricultural

University, Bikaner, Rajasthan, India

\section{Corresponding Author:}

Vipin Kumar

Deptt. of Agricultural Chemistry

\& Soil Science, R B S College

Bichpuri Agra, Uttar Pradesh,

India

\section{Effect of industrial effluent on content of nutrient and heavy metals in plant and soil}

\author{
Vipin Kumar, Nidhi Nagar, Har Mohan Singh Yadav, Devendra Pal and \\ BS Kherawat
}

DOI: $\underline{\text { https://doi.org/10.22271/chemi.2020.v8.i5f.10326 }}$

\begin{abstract}
Effect of continuous irrigation with sewage effluent on soil properties and status of nutrients and pollutant elements in soils and plants in the adjoining areas of Agra and Mathura cities of Uttar Pradesh was ascertained. The physical properties of soils improved due to sewage water irrigation. An appreciable increase in organic carbon available $\mathrm{N}, \mathrm{P}, \mathrm{K}$ contents was recorded in the sewage water irrigated soils. Electrical conductivity of sewage water irrigated soils was much below the threshold limit of salinity. Application of sewage water resulted in the accumulation of heavy metals in surface soil. The mean contents of total $\mathrm{Cd}, \mathrm{Cr}, \mathrm{Pb}$ in the soils irrigated with sewage water were $2.85,75.40$ and $40.26 \mathrm{mg}$ $\mathrm{kg}-1$, respectively. The mean values of available $\mathrm{Cd}, \mathrm{Cr}$ and $\mathrm{Pb}$ in soils were $0.21,0.33$ and $1.27 \mathrm{mg} \mathrm{kg}$ 1 , respectively. The concentration of $\mathrm{Cr}$ in lettuce, cabbage and berseem plants grown on sewage water was higher as compared to its tolerance level indicating their accumulation in plants. In general, $\mathrm{Cd}$ was relatively higher in lettuce $(0.88 \mathrm{mg} \mathrm{kg}-1)$. On the other hand, berseem contained relatively higher amount of $\mathrm{Cr}$ and $\mathrm{Pb}$.
\end{abstract}

Keywords: Heavy metals, sewage water, soil quality, vegetables

\section{Introduction}

Although, soil acts as physical filter due to its sieving action, a chemical filter due to adsorbing and precipitation of chemical substances and biological filter due to decomposing the organic materials, it does not have infinite capacity to perform these functions. An indiscriminate land application of sewage effluents for long term may lead to such pollution problems. It is being increasingly used for irrigating especially the vegetables grown around most of the cities. However, in the long term use this may contaminate the soil with heavy metals which may pose serious human and animal health hazard. The agricultural land around Agra and Mathura cities is being continuously irrigated with city sewage water for many agricultural crops ${ }^{[1]}$. Extent of contamination is better judge by making comparison of metal contaminated soils with the adjacent non-polluted soils. No investigation has been carried out in sewage irrigated soils of this urban area. The influence of use of sewage irrigation on soil physical and chemical properties and plants essential nutrient status and heavy metal content in soils and plants under sewage irrigated soils is ascertained in the present study.

\section{Materials and Method}

In all 20 disposal sites were selected for this investigation. The sewage water samples were collected from these selected sites located near sewage water canal of Agra and Mathura city. The soil and plant samples were also collected from the same sites. An aliquot of $500 \mathrm{ml}$ of sewage effluents and well water samples with $15 \mathrm{ml}$ of HNO3 was evaporated to near dryness on a hot plate. Then contents were digested with $15 \mathrm{ml}$ of $\mathrm{HNO} 3$ and $20 \mathrm{ml} \mathrm{HClO} 4(70 \%){ }^{[2]}$. The residue was taken in $15 \mathrm{ml}$ of $6 \mathrm{~N} \mathrm{HCl}$ and made to the volume $(50 \mathrm{ml})$ and contents were filtered, the filtrate was then analyzed. The other estimations for characterization of sewage effluents, soil properties, major and micronutrients were carried out by using standard procedures ${ }^{[3]}$. The total heavy metals were estimated by wet digestion (HNO3+HCLO4) and the extractable heavy metals by using DTPA were measured by AAS. Soil pH, EC, CaCO3 and organic carbon were determined by adopting standard procedures ${ }^{[4]}$. 


\section{Result and Discussion}

\section{Characteristics of sewage effluents}

The range of $\mathrm{pH}$ value in sewage water was from 7.80 to 8.50. Thus, the sewage water was alkaline in reaction. The Indian standard Institute prescribed tolerance limits for discharge on land for $\mathrm{pH}$ are 5.9 to 9.0. It is evident from the effluent characteristics data (Table I) that the value of $\mathrm{pH}$ did not exceed the prescribed ISI limits. It is, therefore, concluded that sewage water may be used safely for growing various crops ${ }^{[5]}$. The total dissolved solids (TDS) in the effluents (1250-2255 mg $L^{-1}$ ) were higher as compared to the permissible limit of $450 \mathrm{mg} L^{-1}$, However, still the values of TDS are well below the recommended maximum concentration of $3000 \mathrm{mg} L^{-1}$ for irrigation water as per criteria, $2100 \mathrm{mg} \mathrm{L}^{-1}$ as suggested by ISI specification (ISI 1982) for city effluents composition suggested for effluents to be discharged on land. Among the basic anions, the chlorides 7.90-18.25 me $L^{-1}$ were higher than recommended level of 4 me $L^{-1}$.The bicarbonate content was more in the effluents (152.50-274.00

me $\left.L^{-1}\right)$ suggesting that these levels are toxic since they exceed 1.5 me $L^{-1}$ recommended level ${ }^{[6]}$. The higher bicarbonates, chlorides and sulphate have also observed in calcutta city sewage effluents. The residual sodium carbonate(RSC) of sewage effluents(2.50-4.00 me $\left.L^{-1}\right)$ was quite above the safe limit of RSC of 1.25 me $L^{-1}$.The higher ammoniacal - nitrogen in sewage water (17.02-19.70 $\mathrm{mg} \mathrm{L}^{-1}$ ) recorded is due to considerable amount of suspended organic solids which undergo decomposition anaerobically resulting in more accumulation of ammoniacal nitrogen than the nitrate nitrogen. The nitrate nitrogen $(0.03-$ $\left.0.06 \mathrm{mg} L^{-1}\right)$ was low as compared to the recommended maximum concentration of $5 \mathrm{mg} L^{-1}$ [5]. The phosphorus content in sewage water ranged from $0.05-0.09 \mathrm{mg} L^{-1}$. The ranges of $\mathrm{Cd}, \mathrm{Cr}$ and $\mathrm{Pb}$ in sewage effluents were from 0.14 to $0.35,0.35$ to 0.86 and 0.62 to $0.85 \mathrm{mg} L^{-1}$, respectively. The concentration of $\mathrm{Cd}, \mathrm{Cr}$ and $\mathrm{Pb}$ in sewage effluents was higher than the recommended maximum concentration indicating that they can lead to contamination of soil and may be potentially toxic for plants, human and animal health.

\section{Properties of Soils}

The $\mathrm{pH}$ of the soils irrigated with sewage effluents was not much influenced (Table-2). The electrical conductivity in sewage irrigated soils was high due to salt content of sewage water of domestic origin ${ }^{[7]}$. However, it was below the threshold limit to cause salinity hazard to the soil. The lower calcium carbonate content in sewage fed soils can be attributed to the low $\mathrm{pH}$ and acidic component of domestic sewage water. The mean organic carbon content in sewage irrigated soils was $0.79 g^{k g-1}$. The organic carbon content of sewage irrigated soils was higher which is ascribed to the addition of organic matter through long term application of sewage effluents ${ }^{[8]}$. Thus, sewage application to soils is a carbon building/sequestrating and soil quality sustaining practice. All the exchangeable cations in sewage water irrigated soil was higher and the cation exchange capacity of the soils was in general, higher due to higher amount of organic matter in the soils. However, due to organic matter addition through sewage water it might have further increased due to continuous use of sewage water irrigation.

\section{Heavy metal status of soils}

The mean total content of $\mathrm{Cd}, \mathrm{Cr}, \mathrm{Pb}$ in $0-15 \mathrm{~cm}$ layer of contaminated soil was $2.85,75.40$ and $40.26 \mathrm{mg} \mathrm{kg}^{-1}$, respectively. The available heavy metal content was also higher in sewage irrigated soils and the mean value of available $\mathrm{Cd}, \mathrm{Cr}, \mathrm{Pb}$ in $0-15 \mathrm{~cm}$ layer in sewage irrigated soils was $0.21,0.33$ and $1.27 \mathrm{mg} \mathrm{kg}^{-1}$, respectively, Sewage irrigation for 20 year resulted into significant build up of available $\mathrm{Cd}, \mathrm{Cr}, \mathrm{Pb}$ in sewage irrigated soils ${ }^{[1]}$. This may be attributed to the decrease in $\mathrm{pH}$ associated with increase in organic carbon as a result of use of sewage effluents.

\section{Heavy metal Content in Crops}

The higher concentration of $\mathrm{Cr}$ (heavy metals) was observed in the berseem plant than cabbage and lettuce crop grown on these sewage irrigated soil(Table III). The mean concentration of $\mathrm{Cd}, \mathrm{Cr}, \mathrm{Pb}$ was $0.88,4.13$ and $47.63 \mathrm{mg} \mathrm{kg}^{-1}$ in lettuce $0.82,4.50$ and $26.40 \mathrm{mg} \mathrm{kg}^{-1}$ in cabbage and $0.83,4.97$ and $54.00 \mathrm{mg} \mathrm{kg}^{-1}$ in berseem plant grown on sewage fed soils. The cadmium concentration in these three crops was more or less similar and not markedly affected by sewage water. Among the different crops studied, berseem had the higher concentration of lead, the average value in plants growing on sewage water treated soils being $54.0 \mathrm{mg} \mathrm{kg}^{-1} .{ }^{[09]}$ The mean value of $\mathrm{Cd}\left(0.88 \mathrm{mg} \mathrm{kg}^{-1}\right)$ was higher in the leaves of lettuce. The range of $\mathrm{Cr}$ in lettuce, cabbage and berseem were from 2.80-5.20(mean 4.13), 3.40-5.70 (mean 4.50) and 3.40$6.50 \mathrm{mg} \mathrm{kg}^{-1}$ (mean $4.97 \mathrm{mg} \mathrm{kg}{ }^{-1}$ ), respectively. Thus the concentration of $\mathrm{Cr}$ in plants was higher as compared to the suggested permissible tolerance level ${ }^{[09]}$.

\section{Conclusion}

The sewage irrigated soils had higher electrical conductivity and organic carbon. The electrical conductivity although increased due to sewage. It was within the tolerance limit to cause any soil salinity hazard. The heavy metals like $\mathrm{Cd}, \mathrm{Cr}$ and $\mathrm{Pb}$ were found to be accumulated in surface soils and plants due to sewage irrigation. This warrants the potential hazard to soil and plant health in near future suggesting necessity of their safe use after pretreatment in order to make use of sewage effluents as a cheap potential alternative source of plant nutrients in agriculture.

Table 1: Physico-Chemical properties of sewage water.

\begin{tabular}{|c|c|c|}
\hline Properties & Range & Mean \\
\hline $\mathrm{pH}$ & $7.80-8.50$ & 8.12 \\
\hline $\mathrm{EC}\left(\mathrm{dSm} m^{-1)}\right.$ & $1.05-2.42$ & 1.49 \\
\hline TotalSolids(mg $\left.L^{-1}\right)$ & $1250-2255$ & 1727.63 \\
\hline Totalhardness $\left(\mathrm{mg} L^{-1}\right)$ & $160-420.5$ & 266.12 \\
\hline Carbonate $\left(\mathrm{mg} \mathrm{L}^{-1}\right)$ & $30.00-120.0$ & 76.47 \\
\hline Bicarbonate $\left(\mathrm{mg} \mathrm{L} L^{-1}\right)$ & $152.50-274.00$ & 205.40 \\
\hline Chloride $\left(\mathrm{mg} L^{-1}\right)$ & $7.90-18.25$ & 12.74 \\
\hline Phosphate $\left(\mathrm{mg} L^{-1}\right)$ & 0.05-0.09 & 0.068 \\
\hline Sulphate $\left(\mathrm{mg} L^{-1}\right)$ & $4.80-11.00$ & 7.25 \\
\hline $\mathrm{COD}(\mathrm{ppm})$ & $198.00-210.00$ & 203.87 \\
\hline $\mathrm{BOD}(\mathrm{ppm})$ & $340.00-415.00$ & 374.33 \\
\hline $\mathrm{DO}\left(\mathrm{mg} \mathrm{L^{-1 }}\right)$ & $0.70-2.40$ & 1.64 \\
\hline $\operatorname{SAR}\left(\right.$ me $\left.L^{-1}\right)$ & $4.30-7.60$ & 5.98 \\
\hline $\mathrm{RSC}(\mathrm{mmol} / \mathrm{l})$ & $2.50-4.00$ & 3.21 \\
\hline $\mathrm{NH} 4-\mathrm{N}\left(\mathrm{mg} L^{-1}\right)$ & $17.02-19.70$ & 18.42 \\
\hline NO3-N(mg $\left.L^{-1}\right)$ & $0.03-0.06$ & 0.05 \\
\hline $\mathrm{Cd}\left(\mathrm{mg} L^{-1}\right)$ & $0.14-0.35$ & 0.26 \\
\hline $\operatorname{Cr}\left(\mathrm{mg} L^{-1}\right)$ & $0.35-0.86$ & 0.66 \\
\hline $\mathrm{Pb}\left(\mathrm{mg} L^{-1}\right)$ & $0.62-0.86$ & 0.74 \\
\hline
\end{tabular}


Table 2: Physico-Chemical properties of soil irrigated with sewage water

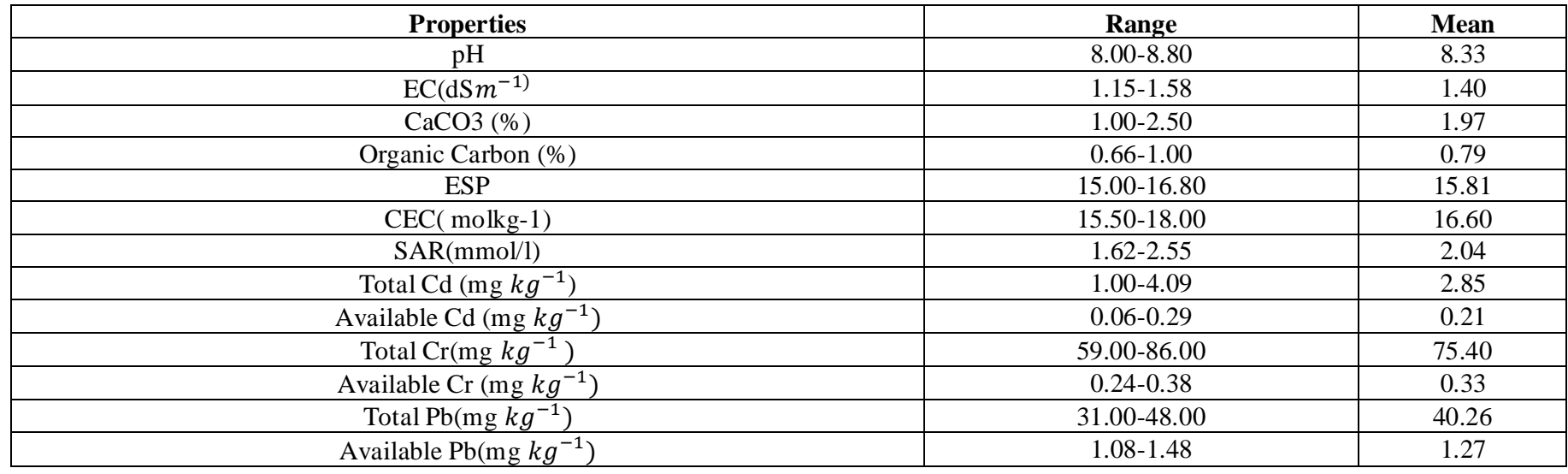

Table 3: Concentration of Heavy Metals in Crops Growing on Soils Treated with Sewage Water

\begin{tabular}{|c|c|c|c|c|c|c|}
\hline Heavy metals $\left(\mathbf{m g} \boldsymbol{k g}^{-1}\right)$ & Lettuce & & Cabbage & Berseem & \\
\hline & Range & Mean & Range & Mean & Range & Mean \\
\hline Chromium & $2.80-5.20$ & 4.13 & $3.40-5.70$ & 4.50 & $3.40-6.50$ & 4.97 \\
\hline Cadmium & $0.61-1.06$ & 0.88 & $0.68-0.98$ & 0.82 & $0.60-1.02$ & 0.83 \\
\hline Lead & 31.00 & 47.63 & $4.00-39.00$ & 26.40 & $37.00-77.00$ & 54.00 \\
\hline
\end{tabular}

\section{References}

1. Rattan RK, Datta SP, Chhonkar PK, Suru Babu K, Singh AK. Long term impact of irrigation with sewage effluents on heavy metal content in soil, crops and ground water- a case study Agriculture Ecosystems and Environment. 2005; 109:310-322.

2. Brar MS, Malhi SS, Singh AP, Arora CL, Gill KS. Sewage water irrigation effects on some potentially toxic trace elements in soils and potato plant in north western India. Canadian Journal of Soil Science. 2000; 80:465471.

3. APHA. Standard methods for the examinations of water and waste water, American public health association, $16^{\text {th }}$ Edn. Washingtion, USA, 1985.

4. Page AL, Miller RH, Keeney DR. Methods of soil analysis. Part 2, $2^{\text {nd }}$ Edn. Soil Science society of America Inc. Madison, Wisconsin, USA, 1982.

5. FAO. Water quality for agriculture (R.S.Ayes and D.W.Westcot, Eds) Irrigation and drainage paper 29 Rev. a, FAO, Rome, 1985, 1749.

6. Maiti PS, Sah KD, Gupta SK, Banerjee SK. Evaluation of sewage sludge as a source of irrigation and manure. Journal of the Indian Society of Soil Science. 1992; 40:167-172.

7. Khurana MPS, Meharban Singh, Nayyar VK. Assessment of heavy metal rentamination in soils and plants irrigated with sewage waters containing industrial effluents in district amritsar, Punjab, Indian Journal of Environment and Rcoplantation. 2004; 8:221-228.

8. Rattan RK, Datta SP, Singh AK, Chhonkar PK, Suribabu $\mathrm{K}$. Effect of long term application of sewage effluents on available nutrients and available water status in soil under Keshopur effluents irrigation scheme in Delhi. Journal of Water Management. 2001; 9:21-26.

9. Naidu R, Kookuna RS, Oliver OP, Rogers S, Mc Laughlin MJ. Contaminants and soil Environment in the Australia Pacific Region, Kluwer Acedemic Pub. London, 1996. 